\title{
China's proposing behavior in Global Governance: the cases of the WTO Doha Round negotiation and G-20 process
}

\author{
As propostas de conduta da China na Governança Global: \\ os casos de negociação da OMC na Rodada Doha e os \\ processos do G-20
}

http://dx.doi.org/10.1590/0034-7329201400208

HONGSONG LIU*

Rev. Bras. Polít. Int. 57 (special edition): 121-137 [2014]

\section{Introduction}

As "the collective management of common problems at the international level" , global governance aims to address global issues as well as buttress and shape global order. Due to the absence of central authority in the international system, states play a central role in global governance, though non-state actors are indispensable participants. By creating and acting through various international institutions, states manage global issues beyond borders collectively, thus construct and maintain global order. As such, the relationship between states and international institutions and states' behavior in international institutions are crucial aspects of their engagement in global governance. Accordingly, the key aspect of China's participation in global governance intertwined with the evolution of its involvement in international institutions lies in its interaction with international institutions.

Since China recovered its legitimate seat in the United Nations in 1971, it has been gradually integrated into the international institutional order and become a systematically important actor on nearly all issues of global governance.

\footnotetext{
* Shanghai International Studies University, School of International and Diplomatic Affairs, Shanghai, China (h.liu16@lse.ac.uk).

1 National Intelligence Council and European Union Institute for Security Studies, Global Governance 2025: At a Critical Juncture (Washington, DC: National Intelligence Council, 2011), iii.
} 
Within this context, China's participation in global governance has entered into the research agenda of International Relations and Chinese Foreign Policy. With regard to the theme of China's participation in global governance, the existing studies primarily focus on China's participation in international institutions, China's compliance with the rules of international institutions and the impact of international institutions on China's domestic politics and foreign policy. Admittedly, taking the relationship between China and international institutions as the research focus fits with the fact that international institutions' key role in global governance. However, the aforementioned three questions do not cover all the aspects of China's engagement in global governance.

Apart from being integrated into the international institutional order and shaped by international institutions, China's shaping efforts in international institutions are also essential part of China's participation in global governance. This article will explore the aspect of China's participation in global governance which has not been paid sufficient attention to, and examine China's proposing behavior in global governance and its main features by clarifying China's reform proposals in the WTO Doha Round negotiation and the G-20 process.

The rest of this article proceeds as follows. The second section reviews the state of research on the theme of China's participation in global governance and illustrates the justification for choosing the cases of the WTO Doha Round negotiation and G-20 process. The third and fourth sections clarify China's reform proposals in the WTO Doha Round negotiation and the G-20 process respectively. The fifth section discusses the main features of China's proposing behavior in global governance based on the two cases. The conclusion summarizes the research findings.

\section{State of research: China and global governance}

Along with the emergence of various global issues and the transformation of China's political economy and foreign policy, China's participation in global governance is increasingly both extensive and intensive. Owing to the need to participate in global governance, China's coping with its foreign relations is increasingly conducted through the channel of international institutions. In light of this, the relationship between China and international institutions has been given close attention to by Chinese and international academia

In international academia, Samuel Kim and Gerald Chen were forerunners in this research field. Their works entitled China, the United Nations and World Order and China and International Institutions were published respectively in 1979 and 1989. The former examined China's voting and diplomatic behavior in the United Nations in the context of West-East confrontation and North-South relationship 
after China recovered its legitimate seat in the UN. ${ }^{2}$ The latter considered the relationship between China and non-governmental organizations since $1971 .{ }^{3}$ From 1990s on, more scholars delved into the research on the relationship between China and international institutions. Harold Jacobson and Michael Oksenberg published a book entitled China's Participation in the IMF, the World Bank, and GATT. This book discussed China's participation in these international economic institutions and the domestic impetus behind its participation. ${ }^{4}$ Afterwards, China joins the World edited by Elizabeth Economy and Michael Oksenberg and Engaging China ${ }^{6}$ edited by Alastair Iain Jonston and Robert Ross were published one after another in 1990s. The works in the two volumes were focused on China's participation in international institutions in a range of issue areas such as international trade and finance, human rights, energy and arms control as well as the change of China's domestic politics and foreign policy behavior in the process of its interaction with international institutions. Besides the research focusing on China's participation in international institutions, some scholars followed with interest China's commitment and compliance in international institutions. Regarding this issue, China's Compliance in Global Affairs ${ }^{7}$ and Beyond Compliance ${ }^{8}$ are typical works. Moreover, Johnston systematically examined China's socialization in the Conference on Disarmament, the Comprehensive Nuclear Test Ban, the Convention on Conventional Weapons, and the ASEAN Regional Forum in his more recent book Social States. In Johnston's view, it is the effect of socialization that caused the major change of China's attitude toward international institutions.

Chinese scholars have also done a lot of work in this research field. Yizhou Wang et al. expounded China's interaction with a variety of international institutions in the issue areas of international economy, arms control, human rights and environmental protection in a relatively comprehensive manner. ${ }^{10}$

2 Samuel Kim, China, the United Nations, and World Order (Princeton: Princeton University Press, 1979).

3 Gerald Chen, China and International Organizations: Participation in Non-Governmental Organizations since 1971 (Oxford: Oxford University Press, 1989).

4 Harold Jacobson and Michael Oksenberg, China's Participation in the IMF, the World Bank, and GATT: Toward a Global Economic Order (Ann Arbor: University of Michigan Press, 1990).

5 Elizabeth Economy and Michael Oksenberg, eds., China Joins the World: Process and Prospects (Washington DC: Brookings Institution Press, 1999).

6 Alastair Iain Johnston and Robert Ross, eds., Engaging China: the Management of An Emerging Power (London: Reutledge, 1999).

7 Gerald Chen, China's Compliance in Global Affairs: Trade, Arms Control, Environmental Protection, Human Rights (Singapore: World Scientific, 2006).

8 Ann Kent, Beyond Compliance: China, International Organizations, and Global Security (Stanford: Stanford University Press, 2007).

9 Alastair Iain Johnston, Social States: China in International Institutions (1980-2000) (Princeton: Princeton University Press, 2008).

10 Yizhou Wang, eds., Mohe Zhong de JianGou: Zhongguo yu Guoji Zuzhi Guanxi de Duoshijiao Toushi (Construction in Contradiction: A Multiple-dimensional Examination on the Relationship between China and International Organizations) [Beijing: Zhongguo Fazhan Chubanshe (China Development Press), 2003]. 
In his more recent book, Wang stressed China's creative involvement by various means including diplomacy in international institutions. ${ }^{11}$ In the book entitled Institutionalized Survival, Jie Liu pointed out that participating in international institutions actively is a strategic choice for China intending to rise peacefully. ${ }^{12}$ Honghua Men provided a historical overview of the relationship between China and international institutions, and proposed that China not only need to participate in international institutions but also ought to play a leading role in agenda-setting and institution-building. ${ }^{13}$ Changhe Su's series of articles on the relationship between China and international institutions explored the profound change of China's diplomatic thinking and behavior and the impact of China's participation in international institutions on its domestic political economy, given that China is undergoing through the transformation of domestic political economy in a rising trend of international institutionalization. ${ }^{14}$ Ye Tian and Jing Ling did a more specific work which explained China's choice of joining International Labor Organization in order to strengthen state autonomy from a political economy perspective. ${ }^{15}$ Yaqin Qin and Ling Wei analyzed how China was attracted by Asian regional cooperation process and thereby participated in regional institutions by employing a theoretical model of process constructivism. ${ }^{16}$

The existing studies primarily dealt with three questions: China's participation in international institutions, China's compliance with the rules of international institutions and the impact of international institutions on China's domestic politics and foreign policy. All of them presumed that the relationship between China and international institutions is a process of being integrated, shaped and impacted. Nevertheless, with the rise of China's overall power and influence,

11 Yizhou Wang, Chuangzao Xing Jieru: Zhongguo Waijiao Xin Quxiang (Creative Involvement: A New Direction in China's Diplomacy) [Beijing: Beijing Daxue Chubanshe (Peking University Press), 2011].

12 Jie Liu, Jizhi Hua Shengcun: Zhongguo Heping Jueqi De Zhanlue Xuanze (Institutionalized Survival: A Strategic Choice for China Intending to Rise Peacefully) [Beijing: Shishi Chubanshe (Current Affairs Press), 2004].

13 Honghua Men, "Guoji Jizhi Yu Zhongguo De Zhanlue Xuanze" (International Regimes and China’s Strategic Choice), Zhongguo Shehui Kexue (Social Sciences in China), no. 2 (2001): 178-187.

14 Changhe Su, "Zhongguo yu Guoji Zhidu: Yixiang Yanjiu Yicheng" (China and International Institutions: A Research Agenda), Shijie Jingji yu Zhengzhi (World Economy and Politics), no. 10 (2002): 5-10; Changhe Su, "Faxian Zhongguo Xin Waijiao: Duobian Guoji Zhidu yu Zhongguo Waijiao Xin Siwei" (Discovering China’s New Diplomacy: Multilateral International Institutions and China’s new Thinking on Diplomacy), Shijie Jingji yu Zhengzhi (World Economy and Politics), no. 4 (2005): 11-16; Changhe Su, "Zhoubian Zhidu yu Zhoubian Zhuyi: Dongya Quyu Zhili Zhong de Zhongguo Tujin" (Neighborhood Institutions and Neighborhoodism: China's Approach to Governance in East Asia), Shijie Jingji yu Zhengzhi (World Economy and Politics), no. 1 (2006): 7-14; Changhe Su, "Zhongguo yu Quanqiu Zhili: Jincheng, Xingwei, Jiegou yu Zhishi" (China and Global Governance: Process, Behavior, Structure and Knowledge), Guoji Zhengzhi Yanjiu (Studies of International Politics), no. 1 (2011): 35-45.

15 Ye Tian and Jing Lin, "Guoji Laogong Biaozhun yu Zhongguo Laodong Zhili: Yizhong Zhengzhi Jingji Xue Fenxi” (International Labor Standards and Labor Governance in China: A Political Economy Perspective), Shijie Jingji yu Zhengzhi (World Economy and Politics), no. 5 (2009): 6-16.

16 Yaqin Qin and Ling Wei, "Jiegou, Jincheng yu Quanli De Shehui Hua: Zhongguo yu Dongya Diqu Hezuo" (Structure, Process and the Socialization of Power: China and Asian Regional Institutions), Shijie Jingji yu Zhengzhi (World Economy and Politics), no, 3 (2007): 7-15. 
China has not accepted all the arrangements in terms of form and substance in international institutions in an entirely passive manner, but rather manifested in an increasingly proactive posture by putting forward proposals for institutional design or reform or proposing to create international institutions with particular form and substance. To a large extent, this phenomenon is ignored by the existing studies. ${ }^{17}$

The purpose of this article is to examine China's proposing behavior in global governance based on illuminating the reform proposals China put forward in the WTO Doha Round negotiation and G-20 process. Choosing the cases of the WTO Doha Round negotiation and G-20 process is justifiable on the following grounds.

First, global economic governance is more salient compared to global governance in other issue areas in contemporary world politics. Economic issues such as trade and finance have not been incorporated into the range of high politics as security issues have been. Nevertheless, given that most states, especially big powers, are not facing pressing security threats, economic issues closely related to the people's living and welfare are definitely in the spotlight in global governance, and therefore in a relatively salient position.

Second, The WTO Doha Round negotiation and G-20 process are critical junctures in the reform of global economic governance. ${ }^{18}$ In such critical junctures, reform proposals have access to the agenda for negotiation or discussion, which encourages states to put forward reform proposals. In the WTO Doha Round negotiation, members attempted to revise some WTO rules. Specifically speaking, developing countries attempted to address the issue of development deficit, while developed countries aimed to further trade liberalization. Nonetheless, the purpose of all the negotiating parties is revising WTO rules and reforming global trade governance. The G-20 mechanism formed shortly after Asian financial crisis in 1997 was initially a forum where the finance ministers and central bank governors of the members discussed how to coordinate macro-economic policies among them. After the eruption of global financial crisis in 2008, the G-20 mechanism was elevated to a regularly held summit in which the leaders of developed economies and developing countries, particularly emerging countries, discussed how to deal with the crisis and coordinate their economic and financial policies. In the G-20 process, the leaders actively engaged in discussion on how to stabilize global financial order, strengthen international financial regulation, resist trade protectionism and rebalance global economy among other issues, set forth their views on the direction and means of the reform of global economic governance,

17 Although Gregory and Ramesh Thakur raised the question whether China will change the rules of global order, their discussion focused on whether, rather than how. See Gregory Chin and Ramesh Thakur, "Will China Change the Rules of Global Order?", Washington Quarterly 33, no. 4 (2010): 119-138.

18 Critical juncture is an important concept of historical institutionalism. In critical junctures, institutional change is apt to occur. See Giovanni Capoccia and Daniel Kelelmen, "The Study of Critical Junctures: Theory, Narrative and Counterfactuals in Historical Institutionalism”, World Politics 59, no. 3 (2007): 341-369. 
and achieved consensus in some aspects. Therefore, the G-20 process became a critical juncture for the reform of global economic governance.

\section{China's reform proposals in the WTO Doha Round negotiation}

In the WTO Doha Round negotiation, developed countries and developing countries put forward different reform proposals by virtue of the opportunity for revising the WTO rules. The core difference of their proposals is that developing countries desired to get special and differentiated treatment, while developed countries aimed to further trade liberalization. This difference in principle hindered developing countries and developed countries from reaching consensus on many issues, including special safeguard mechanism and agricultural subsidy. In general, China supported the development-oriented proposals put forward by developing countries, albeit it was not reluctant to make appropriate compromise for the development of trade liberalization.

In addition, it is evident that China put forward some reform proposals proactively. China's proposals concentrated on the issues of the ruling bodies for the Doha Round, dispute settlement mechanism and anti-dumping rules.

\section{The ruling bodies for the Doha Round}

The Trade Negotiation Committee for the Doha Round which could exert major influence on agenda-setting was largely controlled by developed countries. To restrain developed countries from influencing agenda-setting by controlling the Trade Negotiation Committee, China together with many developing countries put forward a proposal for reforming the selection procedure of the chair of the committee. China demanded that the chairmanship of the Trade Negotiation Committee be rotated among member ambassadors rather than be appointed by the Director-General of the WTO. ${ }^{19}$ In the same vein, China together with many developing countries proposed jointly that: (1) the discretionary authority of the chairs of the six Trade Negotiation Committee subcommittees negotiation subcommittees' chairs in determining which alternative positions are included for consideration in draft proposals should be restrained; (2) alternative draft proposals for negotiation should be determined through deliberation process, but not by the chair of the Trade Negotiation Committee. ${ }^{20}$

Despite the fact that China collaborated in proposing together with other developing countries in the two instances, there was much evidence that China

19 Margaret Pearson, "China in Geneva: Lessons from China's Early Years in the World Trade Organization", in New Directions in the Study of China's Foreign Policy, ed. Alastair Iain Jonston and Robert Ross (Stanford: Stanford University Press, 2006), 253.

20 Pearson, "China in Geneva", 253. 
actually exercised positive influence on the formation and pursuit of the two proposals for reforming the ruling bodies for the Doha Round. ${ }^{21}$

\section{Dispute settlement mechanism}

The dispute settlement mechanism (DSM) provides the WTO members with a legalized procedure for solving trade disputes, and thereby plays an extremely important role in managing the trading relationship among the members. However, due to the lack of necessary expertise and administrative capacity, many developing countries, especially least developed countries, have much difficulty in utilizing this mechanism effectively as developed countries do. For this reason, China put forward four proposals which were designed to protect and promote the interest of developing countries in the working group for DSM.

First, China proposed that: (1) developed countries should maintain a proper restraint from starting the cases against developing countries; (2) developed countries cannot submit more than two cases against the same developing country to the Dispute Settlement Body (DSB) in a calendar year; (3) this restriction should not apply to the cases that developing countries start against developed countries or other developing countries.

Second, regarding the provision about the duration of the consultation procedure, the reform proposal China put forth was that if one or more parties involved in consultation are developing countries, the duration should be prolonged to a maximum of thirty days when the complaining party requests.

Third, with regard to the provision about the establishing time of a panel in Understanding on Rules and Procedures Governing the Settlement of Disputes, China proposed to be revise it as follows: (1) if the complaining party requests, the panel shall be established at the DSB meeting at which such a request first appears as an item on the DSB's agenda, unless the DSB decides by consensus not to establish a panel; (2) if the defending party is a developing country, the current procedure on the establishment of a panel remains to apply, that is, a panel shall be established at the latest at the DSB meeting following that at which the request as an item on the DSB agenda.

Fourth, China proposed that: (1) a general provision applicable to all the developing countries should be added in Understanding on Rules and Procedures Governing the Settlement of Disputes; (2) the provision about special and differentiated treatment for developing countries should be further consolidated so as to be more effective; (3) due to the principle of special and differentiated principle, any stricter provision engendered in the negotiation for the DSM

21 Gregory Chin, "Reforming the WTO: China, the Doha Round and Beyond", in Leadership and Change in Multilateral Trading System, ed. Amrita Narlikar and Brendan Vickers (Leiden: Brill/Martinus Nijhoff Academic Publishers, 2009), 139. 
should not apply to developing countries improperly; (4) developed countries should also help developing countries to participate in the DSM of the WTO by providing technical assistance and capacity training programs; (5) in order to avoid undermining the WTO system more severely, the revision of the Understanding should encourage the disputing parties to seek mutually acceptable solutions, rather than resort to retaliation. ${ }^{22}$

These reform proposals China put forward are in conformity with the principle that the DSM should particularly consider the special situation of developing countries. China's proposing behavior for reforming the DSM is a manifestation of pushing the development-oriented reform of the WTO rules and promoting the development agenda of the Doha Round.

\section{Anti-dumping rules}

The fact that some WTO members abuse the anti-dumping rules in practice is widely denounced by developing countries and some developed countries. As a consequence, the reform of the anti-dumping rules were placed on the agenda of the WTO Doha Round negotiation. In the Doha Round negotiation, Friends of Anti-Dumping (FANS), the US, Canada, Australia, Egypt, India among some other WTO members put forward lots of reform proposals. Soon after joining the WTO, China in collaboration with fifteen WTO members submitted a written report about the anti-dumping of the textiles. Thereafter, China put forward four reform proposals regarding the reform of the anti-dumping rules.

The proposal put forward in 2003 is the most important one. The main content of this proposal was about enforcing anti-dumping discipline more rigorously. On this issue, China proposed: (1) to renew a back-to-back investigation provision, specify the meaning of the terms "special market situation" and "structural normal value" in more detail, and specify the factors which need to be considered when assessing the condition of competition among the imported products from different members or between imported products and domestic products; (2) to restrain the initiating member's investigating authority from assessing the damage arbitrarily, ensure that the causal relationship between dumping imported products and domestic damage is affirmed only if the former is the substantive cause of the latter, prohibit the application of the return-to-zero method explicitly, establish clear guidance for dealing with the normal value of related party transactions, improve the method of confirming all other tariff rates of the non-sampled targeted countries' exporters or manufacturers; (3) make a further explanation on the commitment provisions, restrain the initiating member's

22 Yanqiong Mao, "Lun Zhongguo Yingdui WTO Zhengduan Jiejue Jizhi Gaige de Celue" (China’s Strategy in Response to the Reform of Dispute Settlement Mechanism of the WTO), Jianghuai Luntan (Jianghuai Forum), no. 6 (2008): 55-57. 
investigating authority from rejecting the pricing commitment, and improve the review rules. ${ }^{23}$ Taken together, these reform proposals aimed to restrain the WTO members' discretion from initiating anti-dumping investigation arbitrarily and abusing anti-dumping measures as well as prevent anti-dumping rules from impeding free trade among the WTO members.

Likewise, the main purpose of the two proposals China put forward in 2007 was restraining the WTO members' discretion. More specifically, for instance, on the issue of the applicants' qualification, China proposed that the circumstance in which the application for anti-dumping is considered as being delivered by domestic industries should be defined clearly; On the issue of sun-set review, China proposed that its use should be restricted to no more than once, that means, the duration of any anti-dumping measure is no more than ten years.

In addition, China put forward some proposals for special and differentiated treatment for developing countries. On this issue, China proposed that: (1) when a developed country adopt anti-dumping measures against a developing country' products, the lesser tariff rate rule should be enforced; (2) the percentage of negligible imports and de minimis dumping margin should be improved; (3) when a developed country adopts anti-dumping measures against a developing country's products, as long as the proposed pricing commitment of the exporters can offset the confirmed dumping margin, the developing country's investigating authority should accept the proposal; (4) if an anti-dumping measure is adopted by a developed country against a developing country's products, the measure should terminate automatically after five years. ${ }^{24}$

From the content of China's proposals on the reform of anti-dumping rules, it can be found that China's proposing behavior was dedicated to offering developing countries more substantive special and differentiated treatment.

\section{China's reform proposals in the G-20 process}

Since the eruption of global financial crisis in 2008, C20 has become the primary platform for global economic governance gradually. At all the past G-20 summits, issues concerning the reform of global economic governance, such as strengthening international financial regulation, reforming international financial institutions, rebalancing global economy, were focal points of the leaders' discussion.. As such, the G-20 process became a critical juncture for the reform of global economic governance. In the G-20 process, China expressed its ideas for the reform of global economic governance proactively.

23 Fei Yu, "WTO Fan Qingxiao Guize Gaige Shuping: Yi Doha Fazhan Yicheng Fan Qingxiao Tanpan wei Zhongxin" (Discussion on the Reform of the WTO Anti-Dumping Rules: With A Focus on the Negotiation of the Anti-Dumping Rules in Doha Development Agenda), Fashang Yanjiu (Studies in Law and Business), no. 4 (2009): 73.

24 Ibid., 74 . 
At the first G-20 summit in 2008, China pointed out clearly that the reform of international financial system should aim at the direction toward establishing a fair, just, inclusive and orderly new international financial order, should strive to create an institutional environment conducive to sound global economic development, and should adhere to comprehensive, balanced, progressive, and effective principles. ${ }^{25}$ At the G-20 London summit in 2009, China emphasized the direction toward establishing a fair, just, inclusive and orderly new international financial order again. ${ }^{26}$ Revolving around this direction, China put forward a series of reform proposals in G-20 summits. China's reform proposals concentrated on the reform of international financial regulation, international financial institutions reform and international monetary system reform.

\section{Reform of international financial regulation}

At the first G-20 summit, to strengthen international financial regulatory cooperation and improve international regulatory system, China put forth four reform proposals: establishing code of conduct for credit rating agencies, increasing the level of monitoring global capital flows, strengthening the supervision of various financial institutions and intermediary organizations, and enhancing the transparency of financial markets and their products. ${ }^{27}$ At the following G-20 summits, China put forth more specific reform proposals on the issues of establishing an early warning mechanism, monitoring the shadow banking system, strengthening the regulation of credit rating agencies, and put forth a principle of simplicity, practicability, accountability, and balancing financial regulation and financial innovation.

With regard to how to implement the principle of simplicity, practicability, and accountability in the reform of international financial regulation, China proposed: (1) to establish an international financial system conducive to the development of the real economy; (2) to establish and enforce strict capital and leverage ratio requirements, incorporate the shadow banking system into the regulatory system, and reformulate unified global accounting standards; (3) to strive to strengthen the supervision of systemically important financial institutions, and take the necessary precautionary measures to prevent the risk of excessive speculation; (4) to emphasize the standards of international regulation

25 "Hu Jingtao Zai Ershi Guo Jituan Lingdao Ren Di Yici Fenghui Shang de Jianghua" (Jingtao Hu’s Speech at the First G-20 Leaders' Summit), http://news.xinhuanet.com/newscenter/2008-11/16/content_10364070. htm (accessed March 12, 2013).

26 "Hu Jingtao Zai Ershi Guo Jituan Lingdao Ren Di Erci Fenghui Shang de Jianghua" (Jingtao Hu’s Speech at the Second G-20 Leaders' Summit), http://news.xinhuanet.com/newscenter/2009-04/03/content_11122834. htm (accessed March 12, 2013).

27 "Hu Jingtao Zai Ershi Guo Jituan Lingdao Ren Di Yici Fenghui Shang de Jianghua" (Jingtao Hu’s Speech at the First G-20 Leaders' Summit), http://news.xinhuanet.com/newscenter/2008-11/16/content_10364070. htm (accessed March 12, 2013). 
in consistency with its core principle while taking the differences among financial markets in different states into full consideration, and improve the relevance and effectiveness of financial supervision; (5) to strengthen the supervision of credit rating agencies, reduce reliance on credit rating agencies, improve code of conduct and system of accountability for credit rating agencies, and in particular develop objective, fair, reasonable and unified sovereign credit rating methods and standards so that the rating results accurately reflect a country's economic situation and credit level. ${ }^{28}$

With regard to how to balance financial regulation and financial innovation, China proposed: (1) to endeavor to solve the systemic and fundamental problems in international financial system, and make the financial system rest on, serve, and promote the development of the real economy; (2) to adhere to high standards and strict requirements, and assess the implementation of the new regulatory standards of each member consistently. ${ }^{29}$

\section{International financial institutions reform}

China's reform proposals concerning international financial institutions reform were designed to increase the representation and voice of developing countries in international financial institutions. At G-20 summits, China proposed: (1) to reform the generating mechanism of the executive board in international financial institutions so as to increase the representation and voice of developing countries in international financial institutions; $;^{30}$ (2) to reform the governance structure of the IMF and World Bank so as to increase the representation and voice of developing countries; ${ }^{31}$ (3) to strive to increase the representation and voice of developing countries, continue to promote the reform to achieve substantive progress, reform the existing decision-making procedures and mechanisms of international financial institutions, and promote more extensive and effective participation of all parties; ${ }^{32}$ (4) to continue to promote the reform of international

28 "Hu Jingtao Zai Ershi Guo Jituan Lingdao Ren Di Sici Fenghui Shang de Jianghua" (Jingtao Hu’s Speech at the Fourth G-20 Leaders' Summit), http://news.xinhuanet.com/world/2010-06/27/c_12269632.htm (accessed March 18, 2013).

29 "Hu Jingtao Zai Ershi Guo Jituan Lingdao Ren Di Wuci Fenghui Shang de Jianghua” (Jingtao Hu’s Speech at the Fifth G-20 Leaders' Summit), http://news.xinhuanet.com/world/2010-11/12/c_12766973.htm (accessed March 18, 2013).

30 "Hu Jingtao Zai Ershi Guo Jituan Lingdao Ren Di Yici Fenghui Shang de Jianghua" (Jingtao Hu’s Speech at the First G-20 Leaders' Summit), http://news.xinhuanet.com/newscenter/2008-11/16/content_10364070. htm (accessed March 20, 2013).

31 "Hu Jingtao Zai Ershi Guo Jituan Lingdao Ren Di Erci Fenghui Shang de Jianghua" (Jingtao Hu’s Speech at the Second G-20 Leaders' Summit), http://news.xinhuanet.com/newscenter/2009-04/03/content_11122834. htm (accessed March 20, 2013).

32 "Hu Jingtao Zai Ershi Guo Jituan Lingdao Ren Di Sanci Fenghui Shang de Jianghua" (Jingtao Hu’s Speech at the Third G-20 Leaders' Summit), http://news.xinhuanet.com/politics/2009-09/26/content_12112502.htm (accessed March 20, 2013). 
financial institutions, accelerate the completion of the IMF quota adjustment, and push more persons from emerging countries and developing countries to be appointed as executives in international financial institutions so as to increase the representation and voice of developing countries; ${ }^{33}$ (5) to continue to be committed to choose the high-level executives in international financial institutions based on a fair principle, increase the proportion of middle-level and high-level executives from developing countries, to resolve the problem of executive deficit for developing countries in the institutional framework of international financial institutions. ${ }^{34}$

Largely as a result of China and other developing countries' efforts, the G-20 members committed to increase emerging countries and developing countries' quota share in the IMF to at least $5 \%$ and increase developing countries and transition economies' voting rights in the World Bank to at least 3\% at the G-20 Pittsburgh summit in 2009. At the G-20 Toronto summit in 2010, the G-20 members committed to increase the proportion of officials and scholars from emerging countries appointed as high-level executives in the IMF, World Bank and other international financial institutions, and complete the IMF quota reform at the Seoul Summit. ${ }^{35}$

In addition to increasing the representation and voice of developing countries in international financial institutions, China has put forward some proposals on the issues of establishing a timely and efficient crisis response and rescue mechanism, reinforcing the IMF's aid to developing countries, increasing the total capital of the IMF, strengthening the IMF's supervision on the macroeconomic policies of all the parties especially the major reserve currency issuing economies, strengthening the IMF's role in monitoring and warning capital flows early, and so on. These reform proposals covering a wide range of content suggests that China not only attached importance to the interest and voice of developing countries, but also underscored the capacity building and effective monitoring of international financial institutions.

\section{International monetary system reform}

Prior to the G-20 London summit in 2009, Chinese Central Bank Governor Xiaochuan Zhou Called for reform of the existing international monetary system and the creation of a super-sovereign international reserve currency which can

33 "Hu Jingtao Zai Ershi Guo Jituan Lingdao Ren Di Sici Fenghui Shang de Jianghua" (Jingtao Hu’s Speech at the Fourth G-20 Leaders' Summit), http://news.xinhuanet.com/world/2010-06/27/c_12269632.htm (accessed March 20, 2013).

34 "Hu Jingtao Zai Ershi Guo Jituan Lingdao Ren Di Wuci Fenghui Shang de Jianghua" (Jingtao Hu’s Speech at the Fifth G-20 Leaders' Summit), http://news.xinhuanet.com/world/2010-11/12/c_12766973.htm (accessed March 20, 2013).

35 Xiao Li and Yongqi Feng, "Guoji Huobi Tixi Gaige de Jiti Xingdong yu Ershi Guo Jituan de Zuoyong" (The Collective Action of International Monetary System Reform and the Role of G-20), Shijie Jingji yu Zhengzhi (World Economy and Politics), no. 2 (2012): 137. 
replace the US dollar hegemony, and suggested that the issuing and the available range for the use of Special Drawing Rights (SDRs) should be expanded in the short term in order to reduce the global economy's dependence on the US dollar in his published article. ${ }^{36}$ This proposal was paid close attention to internationally, and gained support of some emerging countries including Brazil and Russia. Xiaochuan Zhou's radical proposal on international monetary system reform did not represent the official position of Chinese government. In the G-20 process, China advocated reform of the existing international monetary system, but did not acknowledge the feasibility and operability of a super-sovereign international reserve currency.

Regarding international monetary system reform, China proposed to improve the regulatory mechanism of reserve currencies, maintain relative stability of major reserve currencies, and promote the diversification and rationalization of international monetary system. ${ }^{37}$ Given that the US launched quantitative easing monetary policies, China proposed that major reserve currency issuing economies should adopt responsible policies to maintain a relatively stable exchange rate. ${ }^{38}$ On the issue of expanding the available range for the use of SDRs, at the Cannes summit in 2011, China proposed: (1) to push forward reform of the existing international monetary system steadily, expand the available range for the use of SDRs IMF special drawing rights, and restructure the composition of the basket of SDRs; (2) to establish an international reserve currency system with stable currency value, orderly supply and adjustable total amount. ${ }^{39}$

\section{The main features of China's proposing behavior}

The WTO Doha Round negotiation and G-20 process provided window of opportunity for China to put forward proposals on the reform of global economic governance. China took advantage of the critical junctures to put forward a series of reform proposals. In terms of China's proposing behavior, three main features are worth noting.

First, China advocated the proper adjustment of global governance institutions, instead of seeking to change the basic principles of the existing system of rules. The

\footnotetext{
36 Xiaochuan Zhou, "Guanyu Gaige Guoji Huobi Tixi De Sikao" (Thoughts on International Monetary System Reform), Dangdai Jingji (Contemporary Economy), no. 4 (2009): 1.

37 "Hu Jingtao Zai Ershi Guo Jituan Lingdao Ren Di Erci Fenghui Shang De Jianghua" (Jingtao Hu’s Speech at the Second G-20 Leaders' Summit), http://news.xinhuanet.com/newscenter/2009-04/03/content_11122834. htm (accessed March 20, 2013).

38 "Hu Jingtao Zai Ershi Guo Jituan Lingdao Ren Di Wuci Fenghui Shang De Jianghua" (Jingtao Hu’s Speech at the Fifth G-20 Leaders' Summit), http://news.xinhuanet.com/world/2010-11/12/c_12766973.htm (accessed March 20, 2013).

39 "Hu Jingtao Zai Ershi Guo Jituan Lingdao Ren Di Liuci Fenghui Shang De Jianghua" (Jingtao Hu’s Speech at the Sixth G-20 Leaders' Summit), http://news.xinhuanet.com/world/2011-11/04/c_122235131.htm (accessed March 20, 2013).
} 
multilateral trading system in the framework of the WTO set the following basic principles: (1) non-discrimination principle meaning that the WTO members cannot discriminate trading partners, must give the same treatment to other members (i.e. MFN principle), and must give equal treatment to domestic and international products and services (national treatment principle); (2) freer trade principle meaning that tariff and non-tariff barriers should be reduced continuously through multilateral trade negotiations; (3) more transparency principle; (4) fair trade principle (anti-dumping and anti-subsidy); (6) pro-development principle which means developing countries should be given special and differentiated treatment. ${ }^{40}$ On the above basic principles of the WTO, China did not requested reforms. More importantly, China desired to formulate more explicit and specific rules so as to implement the principles more effectively.

China's reform proposals aiming at the managing board procedure were designed to make agenda-setting in the WTO Doha Round negotiation more transparent. The reform proposals aiming at the dispute settlement mechanism were designed to allow developing countries to reasonable differentiated treatment and prevent developing countries from failing to use this mechanism resulting from lack of technical and administrative capacity. Last but not least, the reform proposals aiming at the anti-dumping rules were designed to reduce the likelihood of being abused in practice and thereby promote fair trade. In a nutshell, China's proposed rule adjustment was to revise the WTO rules in such a way that the revised rules would conform to the basic principles to a larger extent.

In the G-20 process, China's reform proposals included strengthening international financial regulation, increasing the representation and voice of developing countries in international financial institutions, promoting the diversification and rationalization of international monetary system among others. Such a proposing behavior was an endeavor in establishing a fair, just, inclusive and orderly international financial system without intention of changing the basic principles of the existing international financial system. If the proposals were implemented, the existing international financial system would be more effective in promoting the healthy development of global economy under the circumstance that the embedded liberalism would remain the basic principle. Put it differently, China manifested itself as a reform-minded constructor for global economic governance institutions without revisionist intention.

Second, China did not take the lead in the process of proposing jointly with other countries. While proposing jointly with other countries, it was evident that China participated actively and tried to make a difference. In the process of proposing jointly, however, China did not play a leadership role. China's performance in the $\mathrm{G} 20^{41}$ in the WTO Doha Round negotiation was typical in

40 See WTO, Understanding the WTO, $5^{\text {th }}$ ed. (Geneva, 2010).

41 The G-20 in the WTO Doha Round negotiation is an informal group composed of 21 developing countries. 
demonstrating the fact that China did not take the lead while proposing jointly with other countries. At the Cancun Ministerial, China joined the G20 and proposed jointly with Brazil, India and other G20 members. They proposed that developed countries should reduce huge subsidies for their farmers and other domestic support for agriculture, and developed countries should take effective and measurable means to substantially improve market access for agricultural products of developing countries. ${ }^{42}$ China participated actively in information exchange and mutual discussion inside the G20, coordinated negotiating positions with other members, and gave strong support to collective bargaining. Nevertheless, China neither took part in the drafting of the first proposal led by Brazil and India, nor took the lead in choosing specific issues for negotiation and designing negotiating strategy.

In the case of proposing jointly in the G20 in the WTO Doha Round negotiation, China's reluctance to play a leadership role, on the one hand, partly resulted from its diplomatic style, on the other hand, was partly due to the fact that its interest in agricultural issues differed from other G-20 members'. Unlike most other G20 members, China was both seller and buyer in agricultural trade. For the seller's standpoint, China wanted developed countries to reduce agricultural subsidies. As a seller, it was in China's interest to pressure developed countries to improve market access for agricultural products of developing countries. As a buyer, however, it was not in China's interest to exert too much pressure on agricultural issues. As such, participating actively in proposing jointly with other G20 members while refraining from taking the lead was a more reasonable choice which could strike a balance between a seller's interest and a buyer's. In a similar vein, in the process of proposing for improving developing countries' representation and voice in international financial institutions jointly with other BRIC/BRICS countries, China did not play a leadership role, which was linked to the intention to avoid conflicting directly with European countries on the issue of the IMF quota adjustment. Seen from this perspective, if taking the lead would serve China's interest better in proposing jointly with other countries in the future, China would be likely to play a leadership role. ${ }^{43}$

Third, China upheld the principled idea of pro-development in proposing behavior. China's reform proposals in the WTO Doha Round negotiation concentrated on the pro-development principle. This is not only because giving developing countries special and differentiated treatment is in China's interest, but also results from China's identification with the principled pro-development idea. China's reform proposals concerning the DSM in the WTO were based on the

42 Amrita Narlikar and Diana Tussie, "The G-20 at the Cancun Ministerial: Developing Countries and Their Evolving Coalitions in the WTO”, World Economy 27, no. 7 (2004): 952.

43 Collective bargaining can enhance the group members' bargaining power, provided that their interests converge. See Amrita Narlikar, International Trade and Developing Countries: Bargaining Coalitions in the GATT \& WTO (London: Routledge, 2003). 
consideration that developing countries lack expertise and administrative capacity. As China could mobilize sufficient resources to provide intellectual, technical and administrative support for its use of the DSM, and had familiarized and understood the rules of the DSM well since its accession to the WTO, unlike some small developing countries, China did not lack the necessary expertise and administrative capacity for the effective use of the DSM. Therefore, China's proposing behavior on the issue of the DSM reform was not entirely for the sake of its own interest. To some extent, it was guided by the pro-development idea China upheld.

At the G-20 London summit in 2009, China proposed that International financial institutions should provide more assistance to developing countries and IMF should ensure that the new funding is preferred for the less developed countries. ${ }^{44}$ Also, this proposal showed China's identification with the principled pro-development idea, because as the largest developing country with a large amount of foreign currency reserves, China is extremely unlikely to become a bailout object of international financial institutions.

\section{Conclusion}

The WTO Doha Round negotiation and G-20 process were critical junctures for the reform of global economic governance. China put forward a series of proposals on the reform of global economic governance by actively engaging in the critical junctures. This suggests that shaping the rules of international institutions proactively has become essential part of China's engagement in global governance. In global governance, China is not only impacted by the rules of international institutions, but also evident in proposing to reform the rules.

In proposing behavior, China advocated the proper adjustment of global governance institutions, rather than seeking to change the basic principles of the existing system of rules. Partly for national interest, China did not take the lead in proposing jointly with other countries. As the largest developing country, China had no strong interest in revising the existing rules of global economic governance in a development-oriented manner, but still upheld the principled idea of pro-development.

Submitted November 29, 2013 Accepted February 19, 2014

44 "Hu Jingtao Zai Ershi Guo Jituan Lingdao Ren Di Erci Fenghui Shang de Jianghua" (Jingtao Hu’s Speech at the Second G-20 Leaders' Summit), http://news.xinhuanet.com/newscenter/2009-04/03/content_11122834. htm (accessed March 25, 2013). 


\begin{abstract}
This article examines China's proposals on the reform of global governance, and discusses the main features of China's proposing behavior in the cases of the WTO Doha Round negotiation and G-20 Process. The main findings are: (1) in the critical junctures of global governance reform, China engaged the reform of the global governance institutions proactively, and put forward a series of reform proposals; (2) in proposing behavior, China argued the global governance institutions should be properly adjusted without intention to change the basic principles, refrained from playing a leadership role while proposing jointly with other countries, and upheld the principled idea of pro-development.
\end{abstract}

Keywords: Chinese Diplomacy; G-20; Global Governance; International Institutions; WTO.

\title{
Resumo:
}

O presente artigo analisa as propostas da China sobre a reforma da governança global, e discute as principais características de comportamento da China nos casos de negociação da Rodada Doha da OMC e dos Processos do G-20. As principais conclusões são: (1) nos momentos críticos da reforma da governança global, a China envolveu-se na reforma das instituições de governança global de forma proativa, e apresentou uma série de propostas de reforma; (2) na proposição de comportamento, a China defendeu que as instituições de governança global devem ser ajustadas corretamente sem a intenção de mudar os seus princípios básicos, absteve-se de fazer um papel de liderança enquanto propunha a união com outros países, e confirmou a ideia de princípios de pró-desenvolvimento.

Palavras-chave: Diplomacia chinesa; G-20; Governança Global; instituições internacionais; OMC. 